\title{
Adherence of Streptococcus mutans and Adsorption of Salivary Protein to Resin Composites Containing S-PRG Fillers
}

\section{Masato Hotta*, Daisuke Tamura, Hirotomo Kotake, Shusuke Kusakabe, Taiyu Gen, Kazuki Oike}

Division of Oral Functional Science and Rehabilitation, Department of Operative Dentistry, Asahi University School of Dentistry, Mizuho, Gifu, Japan

Email: *w7mhotta@dent.asahi-u.ac.jp

How to cite this paper: Hotta, M., Tamura, D., Kotake, H., Kusakabe, S., Gen, T. and Oike, K. (2017) Adherence of Streptococcus mutans and Adsorption of Salivary Protein to Resin Composites Containing S-PRG Fillers. Open Journal of Stomatology, 7, 158-168.

https://doi.org/10.4236/ojst.2017.73011

Received: February 14, 2017

Accepted: March 10, 2017

Published: March 13, 2017

Copyright $\odot 2017$ by authors and Scientific Research Publishing Inc. This work is licensed under the Creative Commons Attribution International License (CC BY 4.0).

http://creativecommons.org/licenses/by/4.0/

\begin{abstract}
The purpose of this study was to measure the amount of adsorption of various salivary proteins to a resin composite having various amounts of surface pre-reacted glass-ionomer (S-PRG) fillers, and to make a comparative study of the adherence of $S$. mutans to the resin composite covered by various salivary proteins. We experimentally produced resin composites (S-PRG resin) having the basic composition of Bis-GMA/TEGDMA and various amount of the S-PRG fillers ranging between 0 - $60 \mathrm{wt} \%$. Each S-PRG resin block was soaked in 5 kinds of components found in salivary fluid (Mucin 1, Lactoferrin, IgA, Cystatin C, and Lysozyme), and the amount of adsorption was measured by use of a spectrophotometer. The amount of the adsorption of salivary Mucin 1 was higher than that of any other salivary component tested regardless of the percentage of the S-PRG filler. In the case of salivary Lysoxyme used for coating, the amount of its adsorption increased with an increase in the percentage of the S-PRG filler. In addition, resin blocks coated with various salivary proteins were incubated at $37^{\circ} \mathrm{C}$ for 2 hours with radio-labeled $S$. mutans for a quantitative adherence test. Labeled bacteria that adhered to the resin blocks were collected by using an automatic sample combustion system and a liquid scintillation counter. The absorbed salivary components, especially Mucin 1 and Lysozyme, inhibited the adhesion of $S$. mutans to the S-PRG resin; however, these changes were generally directional rather than statistically significant.
\end{abstract}

\section{Keywords}

S-PRG Filler, Salivary Protein, Oral Bacteria, Resin Composite 


\section{Introduction}

The resin composite restoration is widely used due to the spread of the concept of Minimal Intervention (MI) advocated by the Federation Dentaire Internationale (FDI) [1] [2]. It is necessary to think about the risk of secondary caries after restoration because dental plaque is formed on the surface of a resin composite [3]. The surface components of a resin composite may play an important role in the adherence of bacteria to the composite. The adhesion of bacteria to a surface represents an important and the initial stage of dental plaque formation [4]. Plaque does not form directly on the surfaces of a tooth or resin composite but requires first the adsorption of proteins to such a surface, resulting in a layer known as the acquired pellicle. The composition of dental pellicles is mainly based on the selective adsorption of salivary proteins [5] [6].

The surface properties of resin composite material related to bacterial adhesion and plaque formation are affected by the components of the material [7]. A resin composite containing S-PRG filler has unique surface properties compared with other resin composites used in the oral cavity. S-PRG filler particles are produced by pre-reacted glass-ionomer (PRG) technology [8]. With this technology, a glass-ionomer phase is formed on glass particles through the reaction of fluoro-boro-alumino-silicate glass with polycarboxylic acid in the presence of water [9]. An S-PRG filler has fluoride release and recharge ability equivalent to those of glass-ionomer cements [10]. Further, the S-PRG filler was also found to release inorganic elements such as $\mathrm{Al}^{3+}, \mathrm{Sr}^{2+}, \mathrm{Na}^{+}, \mathrm{SiO}_{3}^{2-}$, and $\mathrm{BO}_{3}^{3-}$ [11].

In this present study we examined the adsorption of various salivary components to S-PRG resins and determined how each component affected the adhesion of $S$. mutans to the S-PRG resin surface. In the oral environment, all solid surfaces are covered by an acquired salivary pellicle. The pellicle on tooth enamel and restoration materials is formed by the selective adsorption of salivary proteins. In this viewpoint, the physicochemical properties of a material influence microbial adhesion either directly or through adsorption of salivary proteins [12] [13] [14]. Therefore, there is the possibility for the composition of the pellicle film formed on the surface of an S-PRG resin to influence accumulation of bacteria in the plaque, and the occurrence of secondary caries. The working null-hypothesis was that the amounts of salivary protein adsorption and adherence of $S$. mutans to investigate S-PRG resin composites would not vary between composites containing different amount of S-PRG filler.

\section{Materials and Methods}

\subsection{Specimen Preparation}

Materials used in this study are listed in Table 1. Resin blocks containing 0 wt\% S-PRG resin (unfilled resin), $30 \mathrm{wt} \% \mathrm{~S}$-PRG resin (total inorganic filler contained $49.2 \mathrm{wt} \%$ ) and $60 \mathrm{wt} \%$ S-PRG resin (total inorganic filler contained 79.2 wt\%), were used in this study. These materials were placed into a metallic mold $(4 \times 4 \times 1 \mathrm{~mm})$ and covered with a micro-slide glass. After irradiation for 60 seconds using a visible light curing unit (Wave length: range 370 to $520 \mathrm{~nm}$ with 
Table 1. Resin composite used in this study.

\begin{tabular}{|c|c|c|c|}
\hline Material & Resin type ${ }^{*}$ & Filler type & $\begin{array}{l}\text { S-PRG filler } \\
\text { content rate }\end{array}$ \\
\hline $0 \%$ resin & Bis-GMA/TEGDMA $=60 / 40$ & - & - \\
\hline $30 \%$ resin & Bis-GMA/TEGDMA $=60 / 40$ & $\begin{array}{c}\text { S-PRG filler } \\
\text { (19.2 wt } \% \text { contains the } \\
\text { ultrafine particle) }\end{array}$ & $30 \mathrm{wt} \%$ \\
\hline $60 \%$ resin & Bis-GMA/TEGDMA $=60 / 40$ & $\begin{array}{c}\text { S-PRG filler } \\
\text { (19.2 wt\% contains the } \\
\text { ultrafine particle) }\end{array}$ & $60 \mathrm{wt} \%$ \\
\hline
\end{tabular}

${ }^{*}$ Containing catalyst.

peak at $470 \mathrm{~nm}$ ) (Coltolux50, Yoshida Corp., Tokyo, Japan), the specimens were gently polished with 2000 grid silicon carbide abrasive paper. The polished specimens were cleaned by ultrasonic cleansing for 30 minutes at room temperature and stored at $4^{\circ} \mathrm{C}$ in sterilized distilled water before any tests were performed.

\subsection{Adjustment of Various Saliva Proteins}

Five kinds of salivary proteins 1) Mucin 1; $200 \mathrm{mg} / \mathrm{ml}$, Sigma-Aldrich, St. Louis, MO, USA; 2) Lactoferrin; $40 \mu \mathrm{g} / \mathrm{ml}$, Santa Cruz Biotechnology, Dallas, Texas, USA; 3) IgA; $200 \mu \mathrm{g} / \mathrm{ml}$, Abcam, Cambridge, UK; 4) Cystatin C; $40 \mu \mathrm{g} / \mathrm{ml}$, Upstate Biotechnology, New York, USA; 5) Lysozyme; $200 \mu \mathrm{g} / \mathrm{ml}$, Sigma-Aldrich) were used for the salivary-protein adsorption test. Each salivary component was diluted with sufficient phosphate-buffered saline (PBS; pH 7.4) to approximate its content in human whole saliva.

\subsection{Salivary-Protein Adsorption Test}

Each resin block was suspended in a test tube with $1 \mathrm{ml}$ of the salivary protein fluid and incubated at $37^{\circ} \mathrm{C}$ for 2,8 or 24 hours. Absorbance $\left(\mathrm{OD}_{280}\right)$ of the salivary protein fluid was measured by using a spectrophotometer (U-2000, HITACHI, Tokyo, Japan), and the amount of salivary protein that adsorbed to a $1 \mathrm{~mm}^{2}$ area of the resin block was calculated from the amount of the absorbance of the free protein. Absorbance of the salivary protein solution prior to incubation was taken as a control.

\subsection{Bacteria Adhesion Test (Quantitative Adherence of Radiolabeled Bacteria)}

S. mutans ATCC 25175 was anaerobically inoculated into $50 \mathrm{ml}$ of Trypticase Soy Broth containing $0.5 \%$ yeast extract and $74 \mathrm{kBq}$ of $\left[6-{ }^{3} \mathrm{H}\right]$ thymidine (GE Healthcare, Wauwatosa, Wisconsin, USA) and cultured at $37^{\circ} \mathrm{C}$ for 18 hours. The cells were collected by centrifugation at $8000 \mathrm{~g}$ for 20 minutes with $0.05 \mathrm{M}$ phosphate-buffered saline (PBS; $\mathrm{pH}$ 7.0) at room temperature, and the radiolabeled bacteria were adjusted with PBS to a concentration of $10^{8} \mathrm{CFU} / \mathrm{ml}$.

Each resin block, which had been soaked in one of the five kinds of salivary 
protein solution for 2 hours, was suspended in a beaker with $260 \mathrm{ml}$ of the labeled bacterial fluid at $37^{\circ} \mathrm{C}$ for 1 hour. To remove the non-adhering bacteria, the resin blocks were removed from the beaker and immediately washed 3 times with PBS. Labeled bacteria that had adhered to the resin blocks were quantified by using automatic sample combustion equipment and a liquid scintillation counter (LSC-903, Aloka, Tokyo, Japan). Resin blocks not soaked in the salivary proteins were the control.

\subsection{Observation under a Scanning Electron Microscope (SEM)}

The resin blocks subjected to the bacteria adhesion test were pre-fixed with $2 \%$ glutaraldehyde for 1 hour at $4^{\circ} \mathrm{C}$, washed twice with a buffer $(0.1 \mathrm{M}$ sodium cacodylate) at $\mathrm{pH} 7.4$, fixed with $1 \%$ osmium tetroxide for 30 minutes at $4{ }^{\circ} \mathrm{C}$, and washed twice with the same buffer. Finally, the specimens were dehydrated with alcohol and isoamyl acetate, dried with $\mathrm{CO}_{2}$ by critical point drying, and observed under the SEM.

\subsection{Statistical Analysis}

Differences in measured values $(\mathrm{n}=4)$ among all S-PRG resins were tested by one-way analysis of variance (ANOVA) and a post hoc test (Fisher PLSD test) for multiple comparisons. A probability of less than 0.05 for similarity of distribution was considered to indicate a significant difference.

\section{Results}

\subsection{Salivary Protein Adsorption}

The absorbance $\left(\mathrm{OD}_{280}\right)$ of the salivary protein fluid decreased with the time of incubation of each of the 5 kinds of salivary protein. That is, it was suggested that the salivary proteins had adsorbed to the resin block with an increase in incubation time. Moreover, the amount of adsorption of the salivary proteins fluid increased at the rate of the content of S-PRG filler. The adsorption of the salivary proteins to the S-PRG resin block (especially 30\%,60\%) soaked in Cystatin C or Lysozyme was significantly $(\mathrm{p}<0.05)$ higher than that of those soaked in the other salivary proteins (Figures 1(a)-(e)). The value for the adsorption of Mucin 1 to the resin block surfaces $\left(\mu \mathrm{g} / \mathrm{mm}^{2}\right)$ was greater than that for the other salivary proteins (Figure 2 ).

\subsection{Adhesion of $S$. mutans (Quantitative Adherence of Radiolabeled Bacteria)}

The values for disintegrations per minute $(\mathrm{dpm})$ were significantly $(\mathrm{p}<0.05)$ lower for all resin blocks soaked in any of the five kinds of salivary protein than for those for the unsoaked blocks (control). No significant difference in dpm was obtained with respect to filler content rate, though the dpm value for Mucin 1 and Lysozyme tended to decrease with the increasing S-PRG filler content rate. In addition, the dpm value for Mucin 1 was lower than that for the other four kinds of salivary protein, but not significantly so (Figure 3 ). 


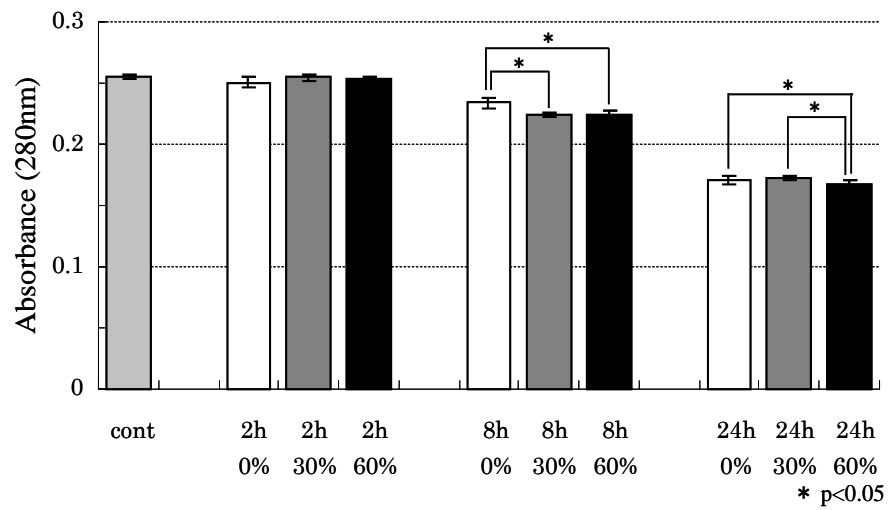

(a)

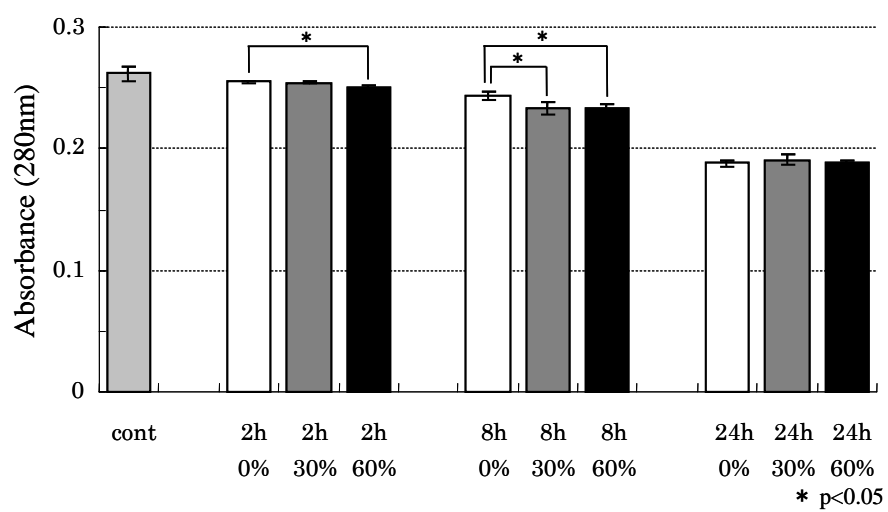

(b)

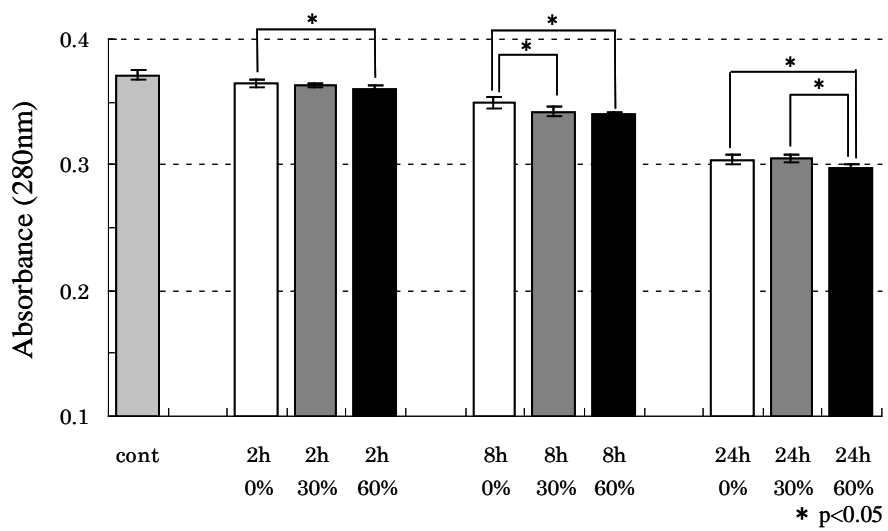

(c)

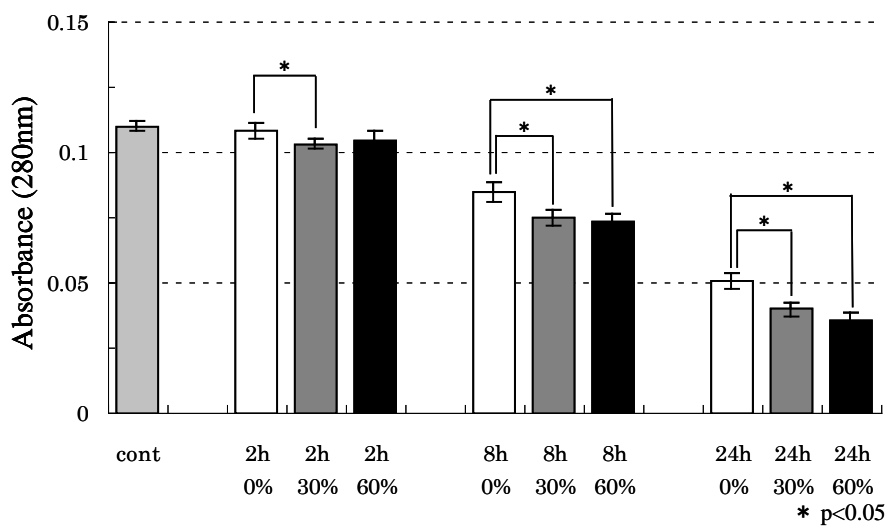

(d) 


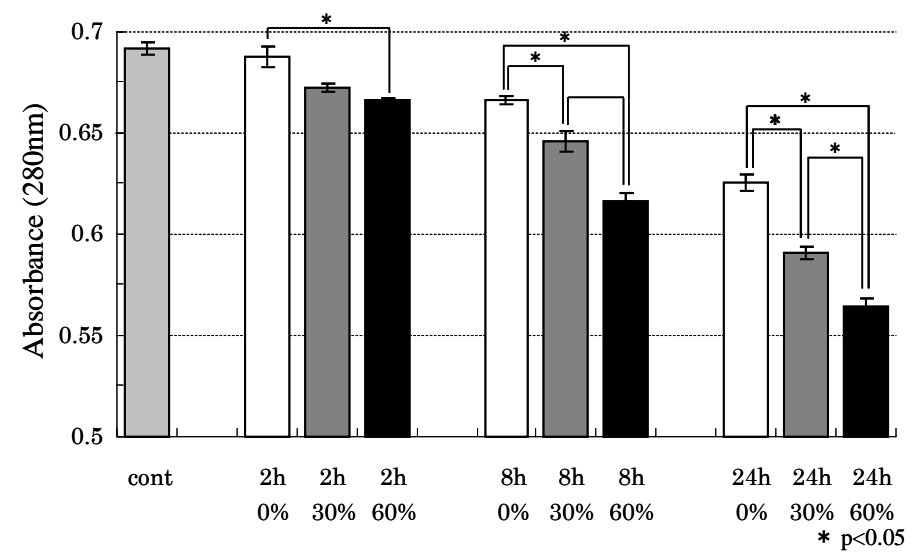

(e)

Figure 1. Mean values for adsorption of the 5 kinds of salivary protein fluid to different S-PRG resin blocks after different time of incubation. (a) Mucin; (b) Lactoferrin; (c) IgA; (d) Cystain C; (e) Lysozyme.

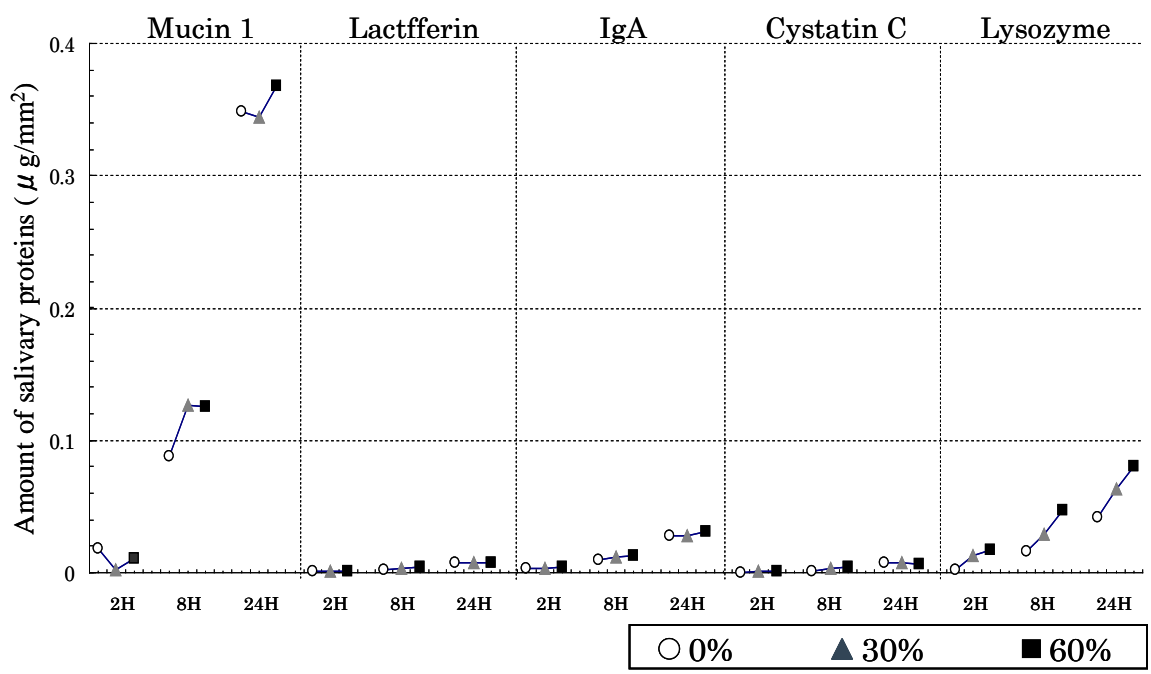

Figure 2. Amount of salivary proteins adsorbed per $1 \mathrm{~mm}^{2}$ area of resin block surface.

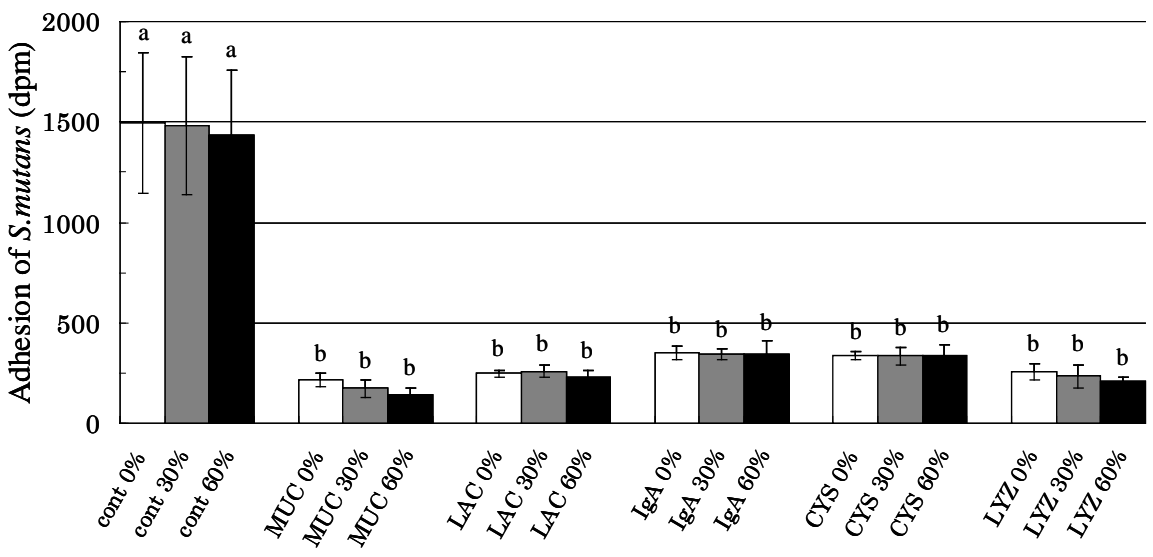

Figure 3. Quantitative adherence of radiolabeled $S$. mutans (No significant difference was found between specimens having the same characters. MUC: Mucin 1, LAC: Lactoferrin, CYS: Cystatin C, LYZ: Lysozyme). 


\subsection{SEM Observation}

Adhesion of $S$. mutans was found on the surfaces of all resin blocks. However, reduced adhesion was observed for the resin blocks that had been incubated with any of the salivary proteins (Figures 4(a)-(f)). Figure 4(b) shows the SEM of $S$. mutans that had adhered to S-PRG resin coated with Mucin 1. Little adhesion found with $S$. mutans regardless of the content rate of the S-PRG filler. Moreover, the number of $S$. mutans that had adhered to the Lysozyme-coated resin tended to decrease with an increase in S-PRG filler content rate.

\section{Discussion}

The current study found that the amount of the salivary protein adsorption varied according to the content of S-PRG filler. Therefore the null hypothesis was rejected. The surface properties of the material used for caries treatment are always influenced by the saliva in the mouth. More than 300 kinds of bacteria exist in the human mouth, and a biofilm is formed on the teeth as a dental plaque [15]. Therefore, it is necessary to know the relationships among the restoration materials, saliva and the plaque in studying about dental materials [16] [17].

The characteristics of the resin composite containing an S-PRG filler, are that salivary proteins are more readily adsorbed than resin composites without S-PRG filler, and the amount of plaque formation is low [18] [19] [20]. In our past in vitro study, electrophoresis analysis (SDS-PAGE) revealed that a resin composite containing the S-PRG filler has the property of adsorbing salivary proteins of $25 \mathrm{kDa}$ or less, whereas the S-PRG filler alone can adsorb salivary proteins of up to $14 \mathrm{kDa}$ [21]. Moreover, the main proteins detected in vivo on the surface of a resin composite containing the S-PRG filler as determined in an immunity SEM method were Cystatin C and Lysozyme [21]. Therefore, we considered the possibility of plaque formation could be influenced by salivary protein in the mouth that is adsorbed on the surface of a resin composite containing S-PRG filler. In our in vitro study, the amount of adsorption of various salivary proteins was measured by using three kinds of resin composite, each having a different content of the S-PRG filler. We also examined the relationship between bacteria adhesion to the resin composite and the salivary protein covering it.

The absorbance $\left(\mathrm{OD}_{280}\right)$ of the salivary protein fluid decreased with increasing incubation time for each of the five kinds of salivary protein tested. Regarding the amounts of each salivary protein that adsorbed to the resin block $\left(\mu \mathrm{g} / \mathrm{mm}^{2}\right)$ regardless of the content of the S-PRG filler, we calculated that Mucin 1 gave the greatest adsorption, followed by Lysozyme. That is, there was almost a correlation between the amounts for various salivary proteins and simulated human whole saliva in this study. Moreover, the amount of adsorption of the Lysozyme increased as the content of the S-PRG filler was increased. The means of interaction between Lysozyme and hydroxyapatite in the mouth is thought to be an electrostatic attraction; because the tooth surface becomes negatively charged when $\mathrm{Ca}^{2+}$ is discharged and Lysozyme, which is positively charged, is then attracted to the teeth [22]. On the other hand, the resin composite containing 

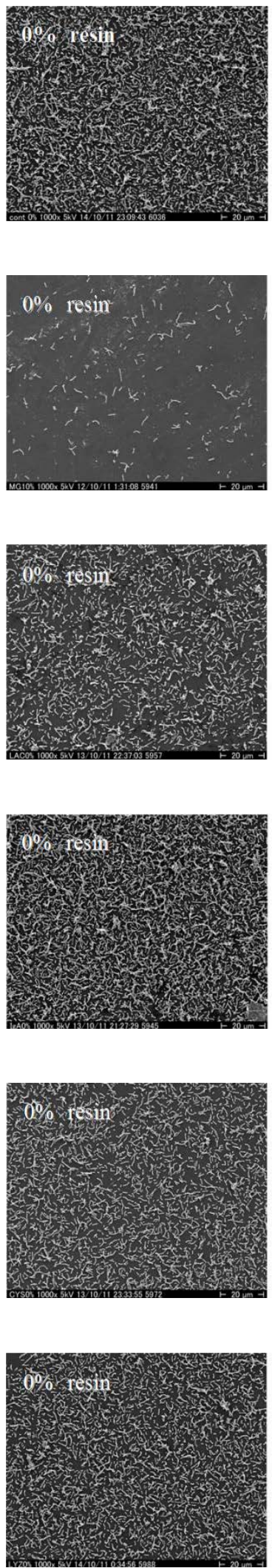

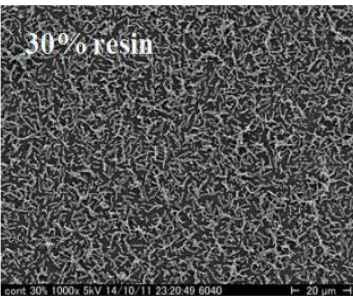

(a)

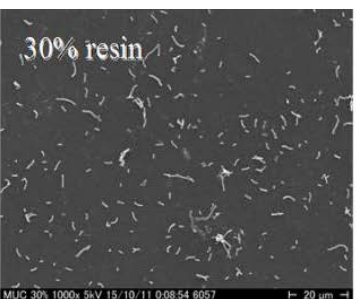

(b)

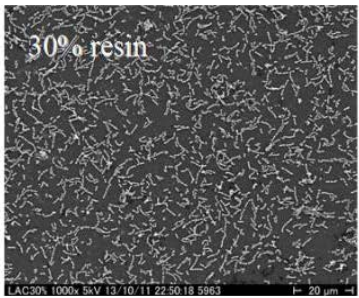

(c)

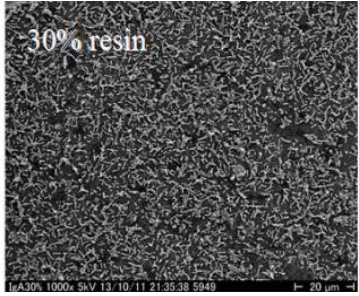

(d)
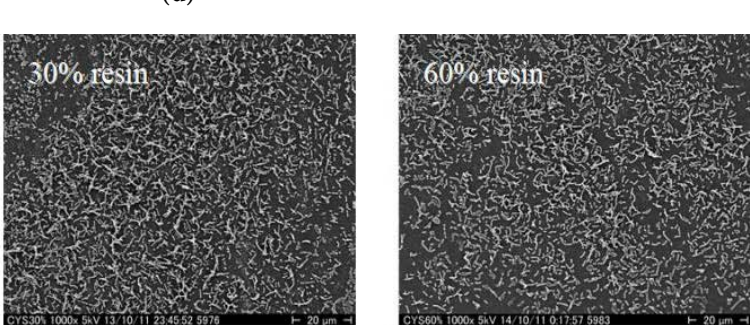

(e)

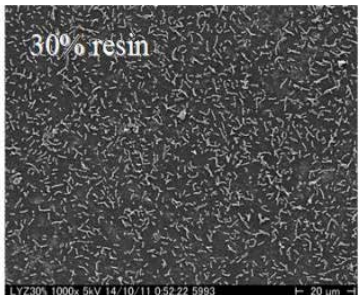

(f)
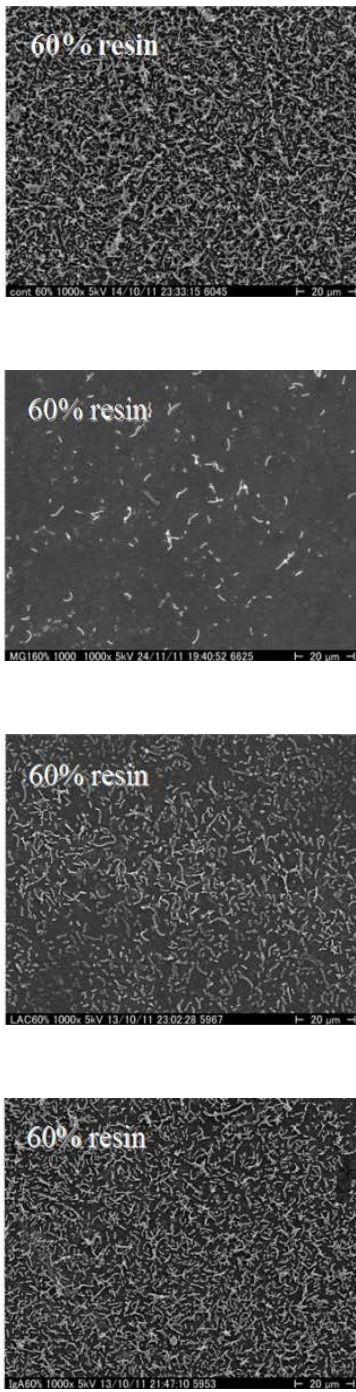

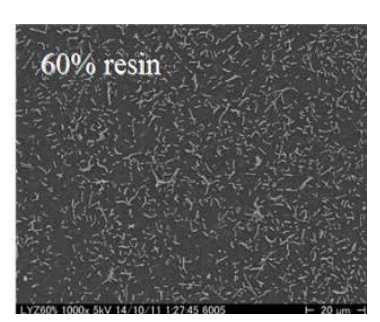

Figure 4. SEM of $S$. mutans adhered to S-PRG resin coated with 5 kinds of salivary protein fluid. (a) Control: non-coated with the salivary protein; (b) Mucin; (c) Lactoferrin; (d) IgA; (e) Cystain C; (f) Lysozyme. 
S-PRG filler discharges various inorganic ions $\left(\mathrm{Al}^{3+}, \mathrm{Sr}^{2+}, \mathrm{Na}^{+}, \mathrm{SiO}_{3}^{2-}, \mathrm{BO}_{3}^{3-}\right)$ in the solution such as saliva, and the amount of discharge is proportional to the content of the S-PRG filler. Therefore, as the ionization potential is high in the case of the resin composite with a high content of the S-PRG filler, the positively charged Lysozyme may unite with the part of resin composite containing the negatively charged S-PRG filler.

We examined bacterial adhesion by using radiolabeled $S$. mutans and by SEM observation. Though the bacteria adhered to all the resin blocks coated with any of the salivary proteins, their adherence was less than that in the control group. Moreover, the resin composites coated with Mucin 1 showed less adhesion than those coated with the other salivary proteins. Adhesion of the radiolabeled bacteria to the Lysozyme-coated composite increased with an increase in the S-PRG filler content, and the number of adherent $S$. mutans seen by SEM observation tended to decrease with the increase in this content. These two experimental results approximated one another, indicating that the amount of adsorption and the kind of the salivary protein influenced the adhesion by $S$. mutans.

The initial conditioning salivary coat plays an important role in bacterial adhesion to a restorative surface [23]. However, it must be pointed out that although the acquired pellicle itself is free of bacteria [24], it is the starting point for microbial colonization on oral hard surfaces, whereby the salivary pellicle acts as a receptor for the initial adhesion of bacteria. Indeed, the formation of oral biofilms on hard surfaces is a complex process that begins with salivary pellicle formation and pellicle adsorption to the surface, and then progresses to passive transport of bacteria to the pellicle surface, followed by irreversible adhesion and multiplication of the attached organisms [25].

Among the five kinds of salivary proteins tested in this study, S. mutans adhesion to resin composites coated with any of these salivary proteins was low. In addition, in the case of Lysozyme there was somewhat of a correlation between the increases in bacterial adhesion with increasing S-PRG filler content. Many anti-bacterial proteins are found in human whole saliva, and Lysozyme is classified as a non-immunoglobulin protein [26]. Moreover, adsorbed Lysozyme is effective in preventing Streptococcus from adhering to the hydroxyapatite covered by saliva [27]. Our finding suggest that the S-PRG filler used in a dental restoration material exposed to endogenous Lysozyme, which is an anti-fungoid salivary protein that is selectively adsorbed, is very profitable to prevent secondary caries.

\section{Conclusion}

The adherence of $S$. mutans was low when the resin blocks were soaked in any of the five kinds of salivary proteins tested regardless of the content of the S-PRG filler. In addition, the amount of adsorption of Lysozyme to the composite increased with increasing content of the S-PRG filler. Moreover, the adhesion of $S$. mutans to the surface of a resin block coated with Lysozyme seemed to become lower with an increase in the content of the S-PRG filler, though no significant 
difference was found.

\section{Acknowledgements}

The authors would like to thank Shofu Inc. for providing the materials needed.

\section{References}

[1] Zanata, R.L., Navarro, M.F., Barbosa, S.H., Lauris, J.R. and Franco, E.B. (2003) Clinical Evaluation of Three Restorative Materials Applied in a Minimal Intervention Caries Treatment Approach. Journal of Public Health Dentistry, 63, 221-226. https://doi.org/10.1111/j.1752-7325.2003.tb03503.x

[2] Mount, G.J. (2003) Minimal Intervention Dentistry: Rationale of Cavity Design. Operative Dentistry, 28, 92-99.

[3] Brambilla, E., Cagetti, M.G., Gaglinani, M., Fadini, L., Garcia-Godoy, F. and Strohmenger, L. (2005) Influence of Different Adhesive Restorative Materials on Mutans Streptococci Colonization. American journal of dentistry, 18, 173-176.

[4] Baier, R.E. and Glantz, P.O. (1978) Characterization of Oral In Vivo Films on Different Types of Solid Surfaces. Acta Odontologica Scandinavica, 36, 289-301. https://doi.org/10.3109/00016357809029079

[5] Hay, D.I. (1973) The Isolation from Human Parotid Saliva of a Tyrosine-Rich Acidic Peptide Which Exhibits High Affinity for Hydroxyapatite Surfaces. Archives of Oral Biology, 18, 1531-1541. https://doi.org/10.1016/0003-9969(73)90128-3

[6] Sönju, T., Christensen, T.B., Kornstad, L. and Rölla, G. (1974) Electron Microscopy: Carbohydrate Analyses and Biological Activities of the Proteins Adsorbed in Two Hours to Tooth Surfaces In Vivo. Caries Research, 8, 113-122. https://doi.org/10.1159/000260099

[7] Hanning, M. (1999) Transmission Electron Microscopy of Early Plaque Formation on Dental Materials In Vivo. European Journal of Oral Sciences, 107, 55-64. https://doi.org/10.1046/j.0909-8836.1999.eos107109.x

[8] Nakatsuka, T., Negoro, N., Aoki, S. and Yasuda, Y. (2000) Introduction of PreReacted Glass-Ionomer (PRG) Technology into Composite Resin. Japan Journal of Conservative Dentistry, 43, 167.

[9] Ikemura, K., Tay, F.R., Kouro, Y., Endo, T., Yoshiyama, M., Miyai, K. and Pashley, D.H. (2003) Optimizing Filler Containing Pre-Reacted Glass-Ionomer Fillers. Dental Materials, 19, 137-146. https://doi.org/10.1016/S0109-5641(02)00022-2

[10] Scougall-Vilchis, R.J., Yamamoto, S., Kitai, N., Hotta, M. and Yamamoto, K. (2007) Shear Bond Strength of a New Fluoride-Releasing Orthodontic Adhesive. Dental Materials Journal, 26, 45-51. https://doi.org/10.4012/dmj.26.45

[11] Fujimoto, Y., Iwasa, M., Murayama, R., Miyazaki, M., Nagafuji, A. and Nakatsuka, T. (2010) Detection of Ions Released from S-PRG Fillers and Their Modulation Effect. Dental Materials Journal, 29, 392-397. https://doi.org/10.4012/dmj.2010-015

[12] Hannig, M. (1997) Transmission Electron Microscopic Study of In Vivo Pellicle Formation on Dental Restorative Materials. European Journal of Oral Sciences, 105, 422-433. https://doi.org/10.1111/j.1600-0722.1997.tb02139.x

[13] Gong, K., Milloux, L. and Hargbreg, M.C. (2000) Salivary Film Expresses a Complex, Macromolecular Binding Site for Streptococcus sanguis. The Journal of Biological Chemistry, 275, 8970-8974. https://doi.org/10.1074/jbc.275.12.8970

[14] Carlen, A., Nikdel, K., Wennerberg, A., Holmberg, K. and Olsson, J. (2001) Surface Characteristics and In Vitro Biofilm Formation on Glass Ionomer and Composite 
Resin. Biomaterials, 22, 481-487.

[15] Christersson, L.A., Zambon, J.J. and Genco, R.J. (1991) Dental Bacterial Plaques: Nature and Role in Periodontal Disease. Journal of Clinical Periodontology, 18, 441-446. https://doi.org/10.1111/j.1600-051X.1991.tb02314.x

[16] Pratt-Terpstra, I.H., Weerkamp, A.H. and Busscher, H.J. (1987) Adhesion of Oral Streptococci from a Flowing Suspension to Uncoated and Albumin-Coated Surfaces. Journal of General Microbiology, 133, 3199-3206. https://doi.org/10.1099/00221287-133-11-3199

[17] Busscher, H.J., Doornbusch, G.I. and Van der Mei, H.C. (1992) Adhesion of Mutants Streptococci to Glass with and without a Salivary Coating as Studied in a Parallel-Plate Flow Chamber. Journal of Dental Research, 71, 491-500. https://doi.org/10.1177/00220345920710031301

[18] Nishio, M. and Yamamoto, K. (2002) The Anti-Dental Plaque Effect of Fluoride Releasing Light-Cured Composite Resin Restorative Material. Japan Journal of Conservative Dentistry, 45, 459-468.

[19] Honda, T., Saku, S. and Yamamoto, K. (2004) Study on the Film Layer Produced from S-PRG Filler. Japan Journal of Conservative Dentistry, 47, 309-402.

[20] Hirose, M., Saku, S. and Yamamoto, K. (2006) Analysis of Film Layer Formed on S-PRG Resin Surface. Japan Journal of Conservative Dentistry, 49, 309-319.

[21] Tamura, D., Saku, S., Yamamoto, K. and Hotta, M. (2010) Adsorption of Salivary Protein to Resin Composite Containing S-PRG Filler. Japan Journal of Conservative Dentistry, 53, 191-206.

[22] Nagadome, H., Kawano, K. and Terada, Y. (1993) Identification of the Adsorbing Site of Lysozyme onto the Hydroxyapatite Surface Using Hydrogen Exchange and 1H NMR. FEBS Letters, 317, 128-130. https://doi.org/10.1016/0014-5793(93)81506-U

[23] Lindh, L. (2002) On the Adsorption Behavior of Saliva and Purified Salivary Proteins at Solid/Liquid Interfaces. Swedish Dental Journal, 152, 1-57.

[24] Lendenmann, U., Grogan, J. and Oppenheim, F.G. (2000) Saliva and Dental Pellicle-A Review. Advances in Dental Research, 14, 22-28. https://doi.org/10.1177/08959374000140010301

[25] Marsh, P.D. (2004) Dental Plaque as a Microbial Biofilm. Caries Research, 38, 204-211. https://doi.org/10.1159/000077756

[26] Stuchell, R.N. and Mandel, I.D. (1983) A Comparative Study of Salivary Lysozyme in Caries-Resistant and Caries-Susceptible Adults. Journal of Dental Research, 62, 552-554. https://doi.org/10.1177/00220345830620050701

[27] Laible, N.J. and Germaine, G.R. (1985) Bacterial Activity of Human Lysozyme, Muramidase-Inactive Lysozyme, and Cationic Polypeptides against Streptococcus sanguis and Streptococcus faecalis. Inhibition by Chitin Oligosaccharides. Infection and Immunity, 48, 720-728. 
Submit or recommend next manuscript to SCIRP and we will provide best service for you:

Accepting pre-submission inquiries through Email, Facebook, LinkedIn, Twitter, etc. A wide selection of journals (inclusive of 9 subjects, more than 200 journals)

Providing 24-hour high-quality service

User-friendly online submission system

Fair and swift peer-review system

Efficient typesetting and proofreading procedure

Display of the result of downloads and visits, as well as the number of cited articles Maximum dissemination of your research work

Submit your manuscript at: http://papersubmission.scirp.org/

Or contact ojst@scirp.org 